\section{Fenomena Afiks Informal Bahasa Indonesia dalam Media Sosial Twitter}

Sunarti Daru Winarti*

Linguistics Master Program, Universitas Gadjah Mada

daruwinarti@hotmail.com

\begin{abstract}
ABSTRAK
Artikel ini bertujuan untuk mendeskripsikan faktor internal dan eksternal penggunaan afiks-afiks informal pada media sosial twitter. Sumber data diperoleh dari media sosial twitter dengan data dari tiga akun twitter terpilih. Purposive sampling digunakan sebagai metode pemilihan akun. Media pembantu pengunduhan tweet adalah vicinitas.id. Pencarian data menggunakan aplikasi WordSmith 4 dan klasifikasi data menggunakan Ms.Excel. Jenis penelitian merupakan penelitian deskriptif kualitatif dan kuantitatif dengan kajian variasi morfologis. Hasil dari penelitian dari faktor internal adalah adanya variasi morfologis pada afiks informal dengan tiga pengelompokan berdasarkan kategori. Pertama afiks informal pembentuk verba, yaitu sufiks -an, sufiks -in, prefiks $\mathrm{N}$-, prefiks ke-, prefiks m-, kombinasi N-in, kombinasi di-in, dan kombinasi m-in. Kedua, afiks informal pembentuk adjektiva terdiri dari sufiks -in dan kombinasi ke-an. Ketiga, afiks informal pembentuk adverbial yaitu prefiks se- dan kombinasi se-an. Faktor eksternal dipengaruhi oleh faktor sosial yang meliputi latar belakang dan usia. Sedangkan alasan penggunaannya dikarenakan sebagai bentuk interaksi keakraban, humor, identitas, informalitas, dan emosi.
\end{abstract}

Kata Kunci: variasi morfologis; afiks; informal; bahasa Indonesia

\title{
PENDAHULUAN
}

Penggunaan ragam informal tidak hanya terjadi pada komunikasi secara lisan akan tetapi juga terjadi pada bentuk komunikasi tertulis. Ragam informal tertulis yang mudah sekali dijumpai adalah pada teks di media sosial. Salah satu media sosial yang banyak digunakan dan memiliki bebas akses dalam pengambilan data untuk penelitian adalah twitter (We Are Social 2020). Penggunaan ragam informal ini tidak hanya dilakukan oleh anak muda, namun tokoh dunia seperti Donald Trump menggunakan komunikasi informal dalam beberapa tweetnya. Bahkan fenomena ini dikaji menjadi salah satu faktor kemenangan Donal Trump dalam pemilu Amerika Serikat. Pada kajian tersebut dikatakan bahwa bahasa informal lebih menujukan kebebasan berpendapat dan memberikan citra tidak kaku terharap sosok Donald Trump kala itu (Ahmadian, Azarshahi, dan Paulhus 2017; Neufeldt 1999).

Dalam penggunaannya, ragam informal dapat berupa kata, frasa, kalimat, atau bahkan morfem tertentu. Maka dari itu, ragam bahasa baik formal maupun informal merupakan lingkup kajian variasi bahasa. Menurut Halliday (1971: 140) ragam merupakan bagian dari variasi bahasa jika dilihat dari segi pemakaiannya. Sifat bahasa yang tidak monolik akan tetapi bervariasi mengakibatkan terjadinya variasi baik internal maupun eksternal. Variasi internal dipengaruhi oleh faktor bahasa itu sendiri misal fonologis, morfologis, sintaksis, dan leksikal. Sedangkan faktor eksternal dipengaruhi oleh faktor sosial dan wilayah atau geografi (Wardhaugh 2006: 22-23; Nababan 1993: 16-25).

Penelitian mengenai ragam informal telah dilakukan oleh beberapa ahli bahasa, selain Ahmadian, Zen (2011) telah melakukan penelitian mengenai afiks informal pada novel. Hasil dari penelitian tersebut diketahui bahwa afiks informal dalam bahasa Indonesia terdiri dari afiks pembentuk verba yang meliputi ke-, ke-an, di-in, -in, N- dengan alomorfnya m-, ny-, ng-, dan nge-. Afiks pembentuk nomina yaitu -an. Afiks pembentuk adjektiva terdiri dari -an dan ke-an. Serta -an, -san, se-an sebagai pembentuk adverbial. Penelitian lainnya adalah penelitian yang dilakukan oleh Devanti \& Merkhamah (2020) yang membahas mengenai afiks pada karangan siswa teks deskripsi kelas VII SMP. Hal yang menarik dari penelitian tersebut dijumpai sufiks informal -an yang seharusnya bentuk afiks formal lebih diutamakan dalam sebuah karangan formal. 
Selain membahas mengenai faktor internal, penelitian ini juga membahas mengenai faktor eksternal yang mempengaruhi penggunaan afiks informal dalam sosial media. Terdapat beberapa penelitian yang mengungkap faktor eksternal penggunaan ragam informal. Bahkan dalam satu penelitian diungkapkan bahwa bahasa yang kasar dapat menjadi baik. Penelitian tersebut membahas mengenai slang yang sangat tidak formal "kasar" dan ekspresi penutur saat menggunakannya. Dari bahasa yang "kasar" tersebut dapat menjadi baik jika dikuti dengan ekspresi-ekspresi tertentu. Dalam hal ini faktor kedekatan dari penutur dan mitra sangat berpengaruh. Selain faktor kedekatan, ekspresi mimik muka dan nada menjadi faktor bagaimana slang kasar bernilai "baik". Selain membahas mengenai faktor ekternal, dalam penelitian tersebut dibahas mengenai alasan penggunaan slang yang "kasar", yaitu untuk memuji, kedekatan seperti pet name, mengungkapkan kekaguman, ungkapan rindu, dan lain sebagainya (Lindberg-Seyersted 1997). Dari penelitian lainnya juga disebutkan bahwa penggunaan ragam informal memiliki fungsi seperti menunjukan identitas, interaksi, kerahasiaan, emosi, humor, informalitas, dan keringkasan percakapan (Arfani dan Rusfitasari 2019). Faktor lainnya diungkapkan oleh Creber \& Giles (1983) bahwa penggunaan ragam informal hanya berlaku pada status pelajar yang setara atau yang lebih muda dari penutur. Jadi tidak berlaku untuk guru atau mentor dan kepada senior mereka.

Dari pembahasan penelitian sebelumnya, penulis memfokuskan kajian pada penelitian ini adalah pada tataran morfologis dengan lingkup kajian afiksasi, khususnya pada penggunaan afiks informal bahasa Indonesia di media sosial twitter. Tujuan dari penelitian ini untuk mengetahui afiks informal yang digunakan di media sosial twitter dan faktor penggunaannya. Hal yang membedakan penelitian ini dengan penelitian sebelumnya, khususnya dengan penelitian Zen (2011) adalah pada objek kajiannya yang berbeda. Pada penelitian ini digunakan media sosial dari twitter dari akun @radityadika dan @lunamaya26. Pemilihan kedua akun tersebut berdasarkan pada jumlah follower terbanyak yang dikeluarkan Databox. Dari 10 akun dipilih, dua akun dipilih berdasarkan tweet teraktif, sehingga terpilih @radityadika dan @lunamaya26. Kedua pemilik akun ini memiliki latar belakang yang berbeda, yaitu Raditya Dika berlatar belakang seorang komedian dan Luna Maya sebagai artis dan model. Dari kedua akun diambil dari satu akun lagi, yaitu @bintangemon (haduhhaduh) yang pada 2020 beberapa kali menjadi tranding twitter. Proses selanjutnya setelah mendapatkan ketiga akun tersebut adalah proses pengunduhan data twitter melalui Vicinitas.io. Data yang terunduh disimpan dalam format txt yang kemudian diolah dengan menggunakan WordSmith 4 untuk mencari afiks yang diinginkan. Pada penelitian ini, penulis menggunakan jenis afiks informal yang telah dibahas oleh Zen (2011) sebagai kode pencaharian seperti sufiks -an yang akan terbaca *an, konfiks ke-an ke*an, dan seterusnya.

Pada tahap klasifikasi penulis menggunakan media MS. Excel dengan klasifikasi berdasarkan fungsi afiks dan kemudian dibagi kembali berdasarkan jenis-jenis afiks. Metode ini dapat dikatakan pula sebagai metode simak dengan teknik catat (Sudaryanto 2015). Dalam proses reduksi data penulis melakukan simak secara manual di aplikasi Wordsmith, misalnya untuk memisahkan sufiks-an bentuk formal dan informal. Tahap selanjutnya setelah klasifikasi adalah analisis data, penulis menggunakan metode breaking words down yaitu analisis morfologis untuk menguraikan kata berdasarkan morfem-morfem pembentuknya (Aronoff 1994; Aronoff dan Bybee 1987). Pada tataran analisis faktor eksternal penulis menggunakan pola deskripsi persebaran data internal yang telah terkumpul guna mendukung faktor eksternal. Berikut adalah hasil analisis yang disajikan dalam pembahasan.

\section{HASIL DAN PEMBAHASAN}

Pada pembahasan ini akan dimulai dengan menyajikan bentuk afiks informal diikuti contoh kata berafiks informal dan variasi bentuk formalnya. Setelah analisis secara struktural, tahapan selanjutnya adalah analisis faktor penggunaannya. Berikut pembahasannya.

\section{Faktor Internal}

Faktor internal pada pembahasan ini adalah membahas mengenai variasi morfemis, khususnya afiks informal. Dalam bahasa Indonesia, afiks terbagi menjadi prefiks, sufiks, infiks, konfiks, dan kombinasi afiks. Masing-masing afiks memiliki bentuk, fungsi, dan makna yang berbeda. Sedangkan proses afiksasi itu sendiri adalah proses yang mengubah leksem menjadi kata kompleks (Kridalaksana 2009). Ramlan berpendapat bahwa proses afiksasi adalah "pembubuhan afiks pada sesuatu satuan, baik 
satuan itu berupa bentuk tunggal maupun bentuk kompleks" (Ramlan 2012). Jadi suatu kata dikatakan kata berafiks artinya pada kata tersebut mengandung afiks tertentu. Hal inilah yang kemudian penulis jabarkan pada pembahasan subbab variasi morfemis berdasarkan kategori pembentuk kata.

\section{a. Afiks Informal Pembentuk Verba}

Afiks informal pembentuk verba pada data twitter terdiri dari prefiks, sufiks, dan kombinasi afiks. Dari ketiga kategori yang berhasil dikumpulkan, kategori verba merupakan data terbanyak yang dijumpai dalam tweet ketiga artis di atas. Berikut adalah pembahasan mengenai variasi morfemis dalam ragam informal.

\section{1) Sufiks -an}

Sufiks merupakan afiks yang dibubuhkan di akhir. Pada ragam baku atau formal, sufiks -an juga digunakan, misalnya sufiks -an untuk pembentuk nomina, adjektiva, dan numeralia (Kridalaksana 2009). Maka dari itu pada proses reduksi data harus dilakukan dengan manual karena secara sistem aplikasi tidak bisa membedakan ragam informal dan formal. Maka dari itu harus dilihat dari faktor lain misal afiks pengganti pada ragam formal dan lebih jauh lagi hingga makna sufiks -an pada ragam informal. Misal pada data berikut ini

Tabel 1. Data Sufiks -an

\begin{tabular}{lll}
\hline Sufiks -an & Data di Twitter & Bentuk Baku \\
\hline \multirow{3}{*}{ D + -an } & motoran & berkendara dengan motor \\
& temenan & berteman \\
sebrangan & bersebrangan \\
& chatan & berkirim pesan \\
& facebookan & berfacebookan \\
\hline
\end{tabular}

Berdasarkan data pada tabel 1, terlihat bahwa sufiks -an pada ragam informal berkorelasi dengan prefiks -ber pada bentuk baku. Sedangkan makna yang ditimbulkan pun berkorelasi dengan makna dari prefiks ber-. Misal pada bentuk temenan, sufiks -an pada bentuk tersebut memiliki makna 'saling', pada motoran, sufiks -an memiliki makna 'mengendarai'. Bentuk seberangan, sufiks -an memiliki makna 'dalam keadaan'. Bentuk chatan, sufiks -an dapat bermakna 'saling' atau 'sedang melakukan...'. Maka dari, dapat dikatakan bahwa antara sufiks -an pada ragam informal dan prefiks ber- saling berkorelasi dalam makna.

\section{2) Sufiks -in}

Jika sebelumnya membahas mengenai sufiks -an, ternyata terdapat sufiks lain yaitu sufiks -in. Sufiks -in dalam penelitian ini memiliki persebaran data yang lebih banyak jika dibandingkan dengan afiks lainya, yaitu 103 kata untuk sufiks -in berbanding 98 prefiks N-. Berikut adalah contoh data penggunaan sufiks -in.

Tabel 2. Data Sufiks -in

\begin{tabular}{lll}
\hline Sufiks -in & Data di Twitter & Bentuk Baku \\
\hline & doain & doakan \\
& pasrahin & pasrahkan \\
& lepasin & lepaskan \\
& wa-in & kirimkan pesan melalui \\
& whatshapp & keluarkan \\
k + -in & keluarin & amsakkan \\
& masakin & fotokan \\
& fotoin & merahkan \\
\hline
\end{tabular}


Berdasarkan pada data tabel 2, dapat terlihat bahwa afiks informal -in berpadanan dengan sufiks -i atau sufiks -kan dalam ragam resmi (Kridalaksana 2009). Jika dilihat dari segi makna, misal bentuk merahin, sufiks -in memiliki makna 'membuat jadi'. Bentuk doain, wa-in, dan fotoin memiliki makna 'benefaktif. Bentuk lepasin, sufiks -in memiliki makna 'membuat jadi'. Jadi dapat diambil kesimpulan, secara makna sufiks -in pada ragam informal berpadanan dengan sufiks -kan pada ragam formal.

\section{3) Prefiks N-}

Prefiks N- merupakan afiks yang diimbuhkan di depan. Kridalaksana menyebut prefiks N- ini adalah simulfiks N-. Keduanya memiliki kesamaan sebagai pembentuk verba (Kridalaksana 2009). Prefiks Natau awalan $\mathrm{N}$ - ini memiliki empat alomorf yaitu n-, ng-, nge-, dan ny. Berikut contoh data dari penggunaan ketiga alomorf.

Tabel 3. Data Prefiks N-

\begin{tabular}{|c|c|c|}
\hline Prefiks N-d & Data di Twitter & Bentuk Baku \\
\hline \multirow{5}{*}{$n-+D$} & tanya & menanyakan \\
\hline & nantang & menantang \\
\hline & nanem & menanam \\
\hline & nusuk & menusuk \\
\hline & nuduh & menuduh \\
\hline \multirow{5}{*}{ ng- + D } & ngalah & mengalah \\
\hline & ngaku & mengaku \\
\hline & ngajak & mengajak \\
\hline & ngambil & mengambil \\
\hline & ngais & mengais \\
\hline \multirow{7}{*}{ ny- + D } & ngasuh & mengasuh \\
\hline & nyambel & menyambal \\
\hline & nyimpen & menyimpan \\
\hline & nyasar & tersasar \\
\hline & cari & mencari \\
\hline & nyantai & bersantai \\
\hline & nyuci & mencuci \\
\hline \multirow{5}{*}{ nge- } & ngemi & makan mie \\
\hline & ngebakso & memakan bakso \\
\hline & ngemis & mengemis \\
\hline & ngelamun & melamun \\
\hline & ngerokok & merokok \\
\hline
\end{tabular}

Berdasarkan pada data 3, dapat dilihat bahwa ketiga alomorf memiliki beserta bentuk bakunya. Alomorf $n$ - biasanya akan muncul apabila bertemu dengan bentuk dasar yang diawali dengan konsonan dental seperti /t/ dan /d/. Misalnya pada bentuk nanya, terbentuk dari $\mathrm{n}-+$ tanya $\rightarrow$ nanya 'menanyakan'. Konsonan /t/ mengalami peluruhan bunyi. Sedangkan pada konsonan /d/ tidak mengalami peluruhan bunyi seperti pada contoh $n-i+$ dengar $\rightarrow$ ndengerin 'mendengarkan'. Sebagian besar alomorf $n$ - memiliki padanan dengan prefiks me- pada bentuk standar atau baku. Selain padanan bentuk afiks, alomorf $n$ - memiliki padanan makna dengan prefiks me-. Misalnya pada bentuk nusuk, terbentuk dari n- + tuduk $\rightarrow$ menusuk.

Alomorf kedua adalah alomorf ng-. bentuk alomorf ini akan muncul apabila $\mathrm{N}$ - bertemu dengan bentuk dasar yang diawali dengan vokal dan bunyi-bunyi velar seperti konsonan /k/. dalam pembentukannya, konsonan /k/ apabila bertemu dengan alomorf ng- akan mengalami peluruhan seperti pada ng- + kalah $\rightarrow$ ngalah. Seperti yang diketahui beberapa konsonan bahasa Indonesia /k, $\mathrm{t}$, s, dan p/ akan mengalami peluruhan pada saat proses morfologis, kecuali untuk kata serapan (Kentjono 1982). Seperti pada alomof n-, alomorf memiliki padanan dengan me- dalam bentuk baku 
dan maknanya. Misalnya pada bentuk ngasuh memiliki makna 'melakukan' dan mengasuh juga memiliki makna 'melakukan'.

Alomorf ketiga adalah alomorf ny-. Sama dengan kedua alomorf sebelumnya, alomorf ny- memiliki padanan dengan me- pada bentuk baku. Alomorf ini muncul apabila $\mathrm{N}$ - bertemu dengan konsonan frikatif (geser) seperti konsonan / $\mathrm{s} /$ dan konsonan /c/. Dalam proses morfologi, kedua konsonan ini akan luruh seperti pada contoh ny- + cuci $\rightarrow$ nyuci atau pada ny- + sambal $\rightarrow$ nyambal. Secara makna, alomorf ny- juga memiliki kesamaan dengan me- pada bentuk baku. Misalnya bentuk nyambal 'membuat' memiliki makna yang sama dengan menyambal pada bentuk baku.

Alomorf keempat adalah alomorf nge-. Alomorf ini memiliki kepadanan dengan afiks me- pada bentuk baku. Menurut persebaran data, alomorf ini biasanya akan muncul pada apabila bertemu dengan bunyi bilabial seperti $/ \mathrm{m} /, / \mathrm{b} /, / \mathrm{p} /$ dan konsonan samping atau konsonan lateral. Secara pemaknaan, alomorf nge- memiliki padanan makna dengan afiks me-. Misal pada bentuk ngelamun 'keadaan' memiliki makna yang sama dengan kata melamun 'keadaan'. Bentuk ngerokok 'melakukan kenikmatan atau menikmati' memiliki makna yang sama dengan bentuk baku merokok, demikian juga berlaku untuk bentuk ngebakso yang memiliki makna 'menikmati'.

\section{4) Kombinasi $\mathrm{N}$-in}

Seperti pada pembahasan prefiks $\mathrm{N}$-, $\mathrm{N}$ - pada kombinasi $\mathrm{N}$-in memiliki alomorf dengan syarat yang telah di bahas pada 2.1.1.3. Maka dari itu, dijumpai pula bentuk $n$-in, ng-in, nge-in, dan ny-in. Di bawah ini contoh cari kombinasi $\mathrm{N}$-in.

Tabel 4. Data Kombinasi N-in

\begin{tabular}{lll}
\hline Kombinasi $\mathbf{N}$-in & Data Twitter & Bentuk Baku \\
\hline \multirow{2}{*}{$\mathbf{N}$-in + D } & ngedoain & mendoakan \\
& ngabisin & menghabiskan \\
& ngeluarin & mengeluarkan \\
& nyalahin & menyalahkan \\
\hline
\end{tabular}

Dari data 4, terlihat bahwa bentuk kombinasi $\mathrm{N}$-in memiliki padanan pada bentuk baku me-kan. Misal nge-in + Doa $\rightarrow$ ngedoain berpadanan dengan me-kan + doa $\rightarrow$ mendoakan. Selain di lihat dari bentuk, untuk mengetahui padanan atau tidak dapat dilihat dari makna afiks-afiks misa. Misal nyalahin 'kausatif', bentuk bakunya menyalahkan 'kausatif'. Bentuk lain misalnya ngeluarin 'membuat jadi (kausatif)', bentuk bakunya mengeluarkan 'membuat jadi (kausatif). Bentuk ngabisin 'kausatif', bentuk bakunya menghabiskan 'kausatif'. Jika demikian, dilihat dari segi maknanya afiks informal kombinasi $\mathrm{N}$-in memiliki padanan makna dengan kombinasi me-kan pada ragam formal.

\section{5) Kombinasi di-in}

Kombinasi di-in merupakan pembentuk verba pasif. Penggunaannya dalam media sosial Twitter termasuk sering muncul juga meskipun secara frekuensi masih di bawah penggunaan sufiks -in dan prefiks N-. Di bawah ini adalah contoh penggunaan kombinasi di-in pada media sosial twitter.

\section{Tabel 5. Data Kombinasi di-in}

\begin{tabular}{lll}
\hline Kombinasi di-in & Data Twitter & Bentuk Baku \\
\hline di-in + D & dibiarin & dibiarkan \\
& ditinggalin & ditinggalkan \\
& disalahin & disalahkan \\
& diduain & diduakan \\
& dikagumin & dikagumi \\
\hline & ditemanin & ditemani \\
\hline
\end{tabular}

Berdasarkan persebaran data pada tabel 5, terlihat bahwa afiks informal kombinasi di-in memiliki padanan bentuk afiks formal kombinasi di-kan dan di-i seperti pada kasus dikagumin yang 
memiliki bentuk baku dikagumi. Jika dilihat dari pembentukannya di-in + salah $\rightarrow$ disalahin dan dikan + salah $\rightarrow$ disalahkan, keduanya berpadanan atau di-in merupakan bentuk variasi informal dari di-kan. Dalam bentuk baku verba pasif di-i dan di-kan memiliki makna gramatikal yang berkebalikkan dengan me-i dan me-kan (Kridalaksana 2009; Chaer 2008). Maka dari itu untuk mengecek apakah afiks informal di-in dan di-i atau di-kan memiliki makna yang sama, maka dilakukan pengecekan pada bentuk aktif keduanya. Sebagai contoh di bawah ini,

Began 1. Skema Pembentukan Makna

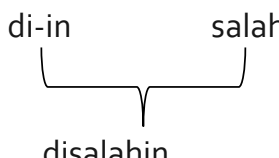

disalahin

'dibuat jadi'

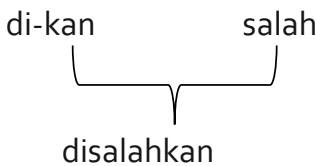

'dibuat jadi'

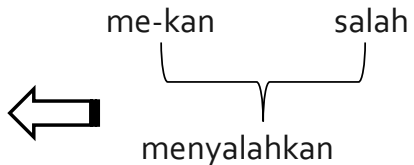

'membuat jadi (kausatif)'

Berdasarkan Chaer (2008) dan Kridalaksana (2009) makna pasif dapat dilihat dari bentuk aktifnya. Maka hal yang dilakukan adalah membuat padanan dari verba aktif baku (standar) kemudian proses verba pasif (standar) dilanjutkan dengan verba pasif non-standar atau informal. Dari bagan 1, dapat dikatakan bahwa di-in memiliki padanan makna dengan kombinasi di-kan dan di-i pada bentuk formal (standar).

\section{6) Prefiks ke-}

Pada bahasa Indonesia, ke biasanya digunakan untuk menunjukan arah atau tempat, misalnya ke Utara, ke Surabaya, ke atas, dan lain sebagainya. Namun pada pembahasan ini yang dimaksud dengan ke- adalah afiks yang diimbuhkan di depan bentuk dasar. Seperti pada tabel di bawah ini.

Tabel 6. Data Prefiks ke-

\begin{tabular}{lll}
\hline Prefiks ke- & Data di Twitter & Bentuk Baku \\
\hline & keminum & terminum \\
ke- + D & ketawa & tertawa \\
& ketuduh & tertuduh \\
& kemasak & termasak \\
& ketipu & tertipu \\
\hline
\end{tabular}

Berdasarkan tabel 6 dapat diketahui bahwa prefiks ke- memiliki padanan prefiks ter-pada bentuk baku. Seperti contoh pada contoh ke- + minum $\rightarrow$ keminum dan ter- + minum $\rightarrow$ terminum. Salah satu contoh tersebut membuktikan bahwa keduanya merupakan padanan. Dilanjutkan pembuktian secara makna, bentuk keminum memiliki makna 'tidak sengaja' dan terminum memiliki makna 'tidak sengaja'. Kemudian bentuk ketawa memiliki makna 'spontan' dan tertawa memiliki makna 'spontan'. Hal tersebut membuktikan bahwa secara makna, prefiks ke- memiliki padanan dengan prefiks teryang merupakan prefiks bentuk baku.

\section{7) Prefiks m- dan Kombinasi m-in}

Pada pembahasan ini, penulis menjadikan satu untuk prefiks $\mathrm{m}$ - dan kombinasi $\mathrm{m}$-in. Hal tersebut dikarenakan keduanya masih berhubungan satu-sama lain. Berikut penjelasan dan contoh data prefiks $m$ - dan kombinasi $m$-in.

Tabel 7. Data Prefiks m- dan Kombinasi $m$-in

\begin{tabular}{lll}
\hline Prefiks m- & Data di Twitter & Bentuk Baku \\
\hline m- + D & mukul & memukul \\
& manjat & memanjat \\
& misah & memisah \\
m-in + D & mantai & beraktivitas di pantai \\
\hline
\end{tabular}


Fenomena Afiks Informal Bahasa Indonesia dalam Media Sosial Twitter

\begin{tabular}{ll}
\hline mungutin & memunguti \\
mijitin & memijati \\
mulangin & memulangkan \\
misahin & memisahkan \\
\hline
\end{tabular}

Berdasarkan data pada tabel 7 dapat diketahui persebaran penggunaan prefiks $\mathrm{m}$ - dan kombinasi min. Prefiks m- memiliki padanan prefiks me- pada bentuk baku. Kombinasi m-in memiliki padanan bentuk baku me-kan. Sebenarnya secara proses morfologis kedua bentuk informal dan formal ini masih saling berhubungan. Misalnya,

\section{Began 2. Pembentukan Kata Mukul}

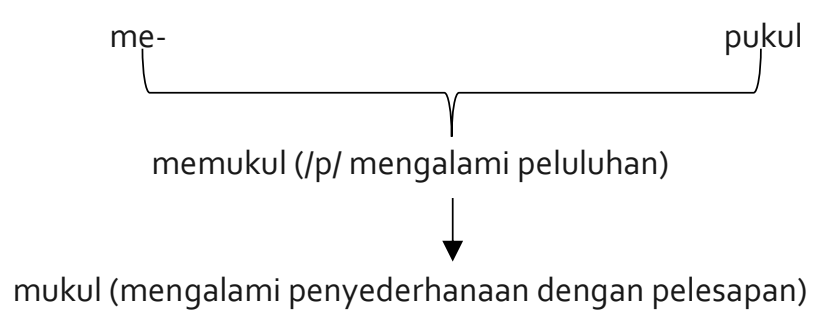

Dalam morfologi terdapat pula derivasi balik seperti pada pungkir $\rightarrow$ mungkir, paju $\rightarrow$ maju. Derivasi balik merupakan "proses pembentukan kata karena bahasawan membentuknya berdasarkan polapola yang ada tanpa mengenal unsur-unsurnya. Akibatnya terjadi bentuk secara historis tidak diramalkan (Kridalaksana 2009)". Jika berdasarkan pendapat Kridalaksana, maka mukul $\rightarrow$ pukul bukan dari bagian derivasi balik, hal tersebut dikarenakan mukul masih berhubungan dengan unsur dasarnya.

Proses selanjutnya apakah m- merupakan padanan me-, dilihat dari makna yang terbentuk. Pada bentuk mukul memiliki makna 'melakukan' dan memukul memiliki makna 'melakukan'. Bentuk lainnya misalnya manjat memiliki makna 'melakukan' dan memanjat memiliki makna 'melakukan'. Kemudian untuk kombinasi m-in, misalnya matahin 'membuat jadi (kausatif)' dan mematahkan yang merupakan bentuk baku memiliki makna 'membuat jadi (kausatif)'. Maka dari itu dapat dikatakan bahwa prefiks $\mathrm{m}$ - memiliki padanan makna dengan me- bentuk formal dan kombinasi $\mathrm{m}$-in memiliki padanan makna dengan me-kan bentuk formal.

\section{b. Afiks Informal Pembentuk Adjektiva}

Afiks informal pembentuk adjektiva terdiri dari sufiks-an dan konfiks ke-an. Dalam bahasa Indonesia, konfiks ke-an juga digunakan dalam bentuk baku seperti kedatangan, kepergian, kemalasan, dan lain sebagainya. Maka dari itu proses reduksi data memerlukan waktu lebih lama karena harus melihat sampai pada tataran makna afiks. Berikut pembahasan dan persebaran data afiks informal pembentuk adjektiva.

Tabel 8. Afiks Informal Pembentuk Adjektiva

\begin{tabular}{|c|c|c|c|}
\hline $\begin{array}{l}\text { Afiks Informal } \\
\text { Adjektiva }\end{array}$ & Pembentuk & Data di Twitter & Bentuk Baku \\
\hline \multirow[t]{3}{*}{$-a n+D$} & & sabaran & lebih sabar \\
\hline & & gantengan & lebih ganteng \\
\hline & & cantikan & lebih cantik \\
\hline \multirow[t]{3}{*}{ ke-an + D } & & kemahalan & terlalu mahal \\
\hline & & keenceranan & terlalu encer \\
\hline & & ketebalan & terlalu terbal \\
\hline
\end{tabular}

Tidak seperti afiks informal pembentuk verba, afiks informal pembentuk adjektiva tidak memiliki banyak variasi. Maka dari itu, penulis menjadikan satu topik pembahasan untuk afiks informal pembentuk adjektiva. Pada tabel 8, dapat terlihat bahwa sufiks informal -an memiliki padanan bentuk baku dengan bentuk "lebih + Dasar". Jika dilihat secara makna sufiks -an memiliki makna 
komparatif. Seperti pada contoh cantik + -an $\rightarrow$ cantikan memiliki makna 'lebih (komparatif)'. Misalnya pada kalimat "cantikan Lunalah dibandingkan dia" (Tw. LM g). Sedangkan untuk kombinasi ke-an pada bentuk informal memiliki padanan bentuk "terlalu + D). Maka dari itu untuk makna kombinasi ke-an memiliki makna 'terlalu...'. Misalnya pada kemahalan memiliki makna 'terlalu...'.

\section{c. Afiks Informal Pembentuk Adverbia}

Afiks informal pembentuk adverbial tidak banyak digunakan seperti halnya adjektiva jika di bandingkan dengan verba. Maka dari itu untuk pembahasannya penulis menjadikan satu sub pembahasan. Berikut pembahasan dan contoh data afiks informal pembentuk adverbial.

Tabel 9. Afiks Informal Pembentuk Adverbia

\begin{tabular}{|c|c|c|}
\hline $\begin{array}{l}\text { Afiks Informal Pembentuk } \\
\text { Adverbia }\end{array}$ & Data Twitter & Bentuk Baku \\
\hline se-an + D & semalaman & sepanjang malam \\
\hline \multirow[t]{2}{*}{ se- + D } & sepulang & setelah pulang \\
\hline & sepeninggal almarhum & $\begin{array}{l}\text { setelah meninggalnya } \\
\text { almarhum }\end{array}$ \\
\hline
\end{tabular}

Berdasarkan contoh data pada tabel 9, terlihat afiks informal pembentuk adjektiva memiliki dua variasi yaitu kombinasi se-an dan prefiks se-. Contoh pembentukan dimulai dari se-an + malam $\rightarrow$ semalaman yang memiliki makna 'seluruh waktu ...". Pada sufiks se- untuk contoh se- + pulang $\rightarrow$ sepulang memiliki makna 'setelah ...".

\section{Faktor Eksternal}

Salah satu penyebab terjadinya variasi adalah faktor sosial. Faktor ini dapat menjadi penentu bentuk komunikasi di media sosial twitter. Selain itu melihat latar belakang ketiganya yang bekerja di dunia entertainment semakin memperkuat dugaan untuk berkomunikasi lebih santai atau menggunakan ragam informal. Jika dilihat dari latar belakang masing-masing, terdapat data sebagai berikut.

\section{Bagan 3. Frekuensi Penggunaan Afiks Informal pada Tweet}

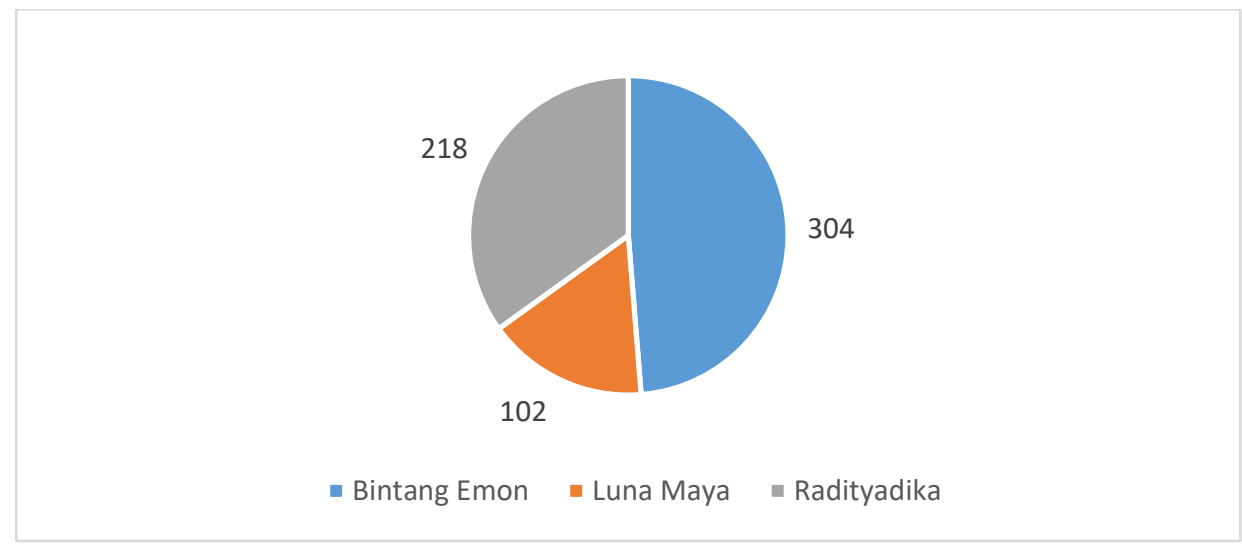

Jika dilihat latar belakang bagaimana nama ketiganya besar di dunia entertainment, maka dapat dikatakan bahwa komedian miliki frekuensi penggunaan bentuk non-standar lebih banyak jika dibandingkan dengan mereka yang besar dari dunia non-komedian, dalam hal ini Luna Maya merupakan seorang artis dan juga model. Sedangkan jika dilihat dari rentang usia Luna Maya (37), Bintang Emon (24), Raditya Dika (36), maka pengguna twitter yang lebih muda dalam hal ini Bintang Emon memiliki frekuensi penggunaan afiks informal yang lebih banyak jika dibandingkan keduanya. $\mathrm{Hal}$ ini menujukan bahwa penggunaan infiks informal dan usia saling keterkaitan dan menunjukan bahwa mereka yang lebih muda cenderung menggunakan ragam santai atau bentuk informal untuk berkomunikasi.

Sedangkan jika dilihat dari jenis kategori afiks, verba menduduki jumlah terbanyak dengan persebaran 471 data berkategori verba, 97 data berkategori adjektiva, dan 56 berkategori adverbial. 
Jumlah ini terdapat beberapa data yang sama dalam kategorinya akan tetapi digunakan pada tweet yang berbeda. Twitter merupakan media berkomunikasi yang menyediakan kolom media menulis pesan yang singkat jika dibandingkan dengan media sosial lainnya. Hal tersebut selaras dengan persebaran data yang mayoritas langsung pada pokok pesan dan peran verba menjadi penting dalam setiap tweet.

\section{Gambar 1. Tangkap Layar Akun @bintangemon “haduhhaduh”}

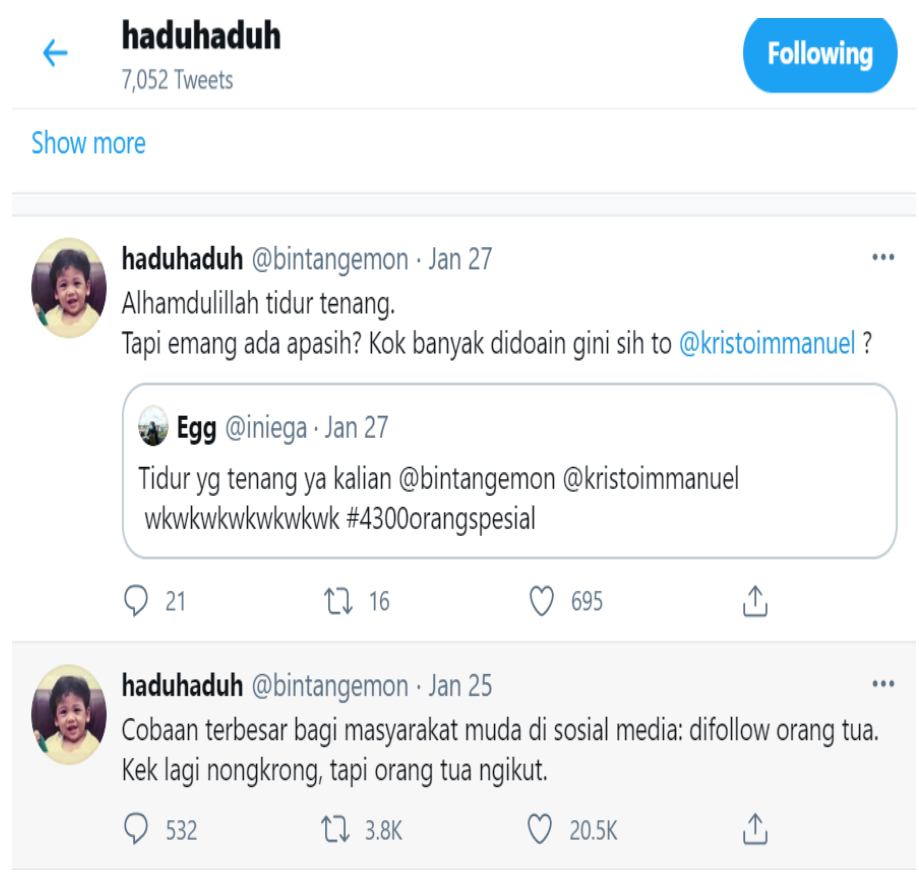

Dari bentuk afiks informal yang ada pada data penelitian juga menunjukan bahwa faktor penggunaan afiks tersebut adalah untuk menyingkat penulisan pesan pada teks di twitter, misalnya memukul menjadi mukul, lebih mahal menjadi kemahalan, lebih cantik menjadi cantikan, terminum menjadi keminum, menusuk menjadi nusuk, dan lain sebagainya. Bentuk-bentuk ini menujukan bahwa, Selain sebagai penyingkat pesan dan informalitas, terdapat beberapa afiks yang digunakan untuk menambahkan nilai humor. Misal pada pesan tangkapan layer di gambar 1.

"Cobaan terbesar bagi masyarakat muda di sosial media: difollow orang tua. Kek lagi nongkrong, tapi orang tua ngikut" (Tw. BE 5)

Pada tweet tersebut jika ngikut disubstitusi dengan mengikuti, maka selera humor bintang emon akan terkesan lebih kaku. Selain itu, afiks informal juga merupakan bentuk interaksi kedekatan, contohnya seperti pada tangkapan layer gambar I pesan yang atas, yaitu pada penggunaan kombinasi di-in untuk membentuk kata didoain.

\section{KESIMPULAN}

Berdasarkan hasil pembahasan di atas, adanya variasi morfem khususnya afiks informal menimbulkan adanya variasi pada afiks lain selain afiks formal. Afiks-afiks informal digunakan untuk membentuk tiga kategori yaitu afiks pembentuk verba, afiks pembentuk adjektiva, dan afiks pembentuk adverbial. Dari ketiga afiks tersebut, afiks pembentuk verba memiliki variasi afiks yang lebih banyak jika dibandingkan dengan adjektiva dan adverbial. Afiks informal pembentuk verba meliputi sufiks -in yang memiliki padanan makna dengan bentuk baku sufiks -kan, sufiks -an yang memiliki padanan makna dengan bentuk baku prefiks ber-, prefiks $\mathrm{N}$ - yang memiliki padanan makna dengan bentuk baku prefiks me-, kombinasi $\mathrm{N}$-in yang memiliki padanan makna dengan bentuk baku kombinasi me-kan, kombinasi di-in yang memiliki padanan makna dengan bentuk baku kombinasi di-kan, prefiks ke- yang memiliki padanan makna dengan bentuk baku prefiks ter-, prefiks m- yang memiliki padanan makna dengan bentuk baku me-, dan kombinasi m-in yang memiliki padanan makna dengan bentuk baku kombinasi me-kan. Afiks informal pembentuk adjektiva terdiri dari sufiks 
-in yang bermakna 'lebih (komparatif)' dan kombinasi ke-an 'terlalu/ lebih (komparatif)'. Afiks informal pembentuk adverbial terdiri dari kombinasi se-an yang bermakna 'selama waktu ...' dan prefiks se- 'setelah ...'. Faktor eksternal yang berpengaruh pada penggunaan afiks-afiks informal adalah faktor sosial yang meliputi usia dan latar belakang pengguna twitter. Sedangkan untuk penyebab penggunaan afiks informal pada tweet di twitter adalah sebagai bentuk interaksi keakraban, informalitasi, nilai humoris, identitas (khususnya pada komedian), dan ekspresi emosi.

\section{DAFTAR PUSTAKA}

Ahmadian, Sara, Sara Azarshahi, dan Delroy L. Paulhus. 2017. "Explaining Donald Trump via Communication Style: Grandiosity, Informality, and Dynamism." Personality and Individual Differences 107 (Maret): 49-53. doi:10.1016/j.paid.2016.11.018.

Arfani, Sri, dan Riri Rusfitasari. 2019. "Slang Used in"Top Five Movie" Directed By Chris Rock." Journal of English Language and Literature (JELL) 4 (01): 39-50. doi:10.37110/jell.v4i01.68.

Aronoff, Mark. 1994. Morphology by Itself. London: The MIT Press.

Aronoff, Mark, dan Joan L. Bybee. 1987. Morphology: A Study of the Relation between Meaning and Form. Language. Vol. 63. doi:10.2307/415386.

Chaer, Abdul. 2008. "Morfologi Bahasa Indonesia." Dalam . Yogyakarta: Reneka Cipta.

Creber, Clare, dan Howard Giles. 1983. "Social context and language attitudes: The role of formalityinformality of the setting." Language Sciences 5 (2): 155-61. doi:10.1016/So388$0001(83) 80020-5$.

Devanti, Haningtyas Martha, dan Markhamah Markhamah. 2020. "Jenis Dan Makna Afiks Pada Karangan Siswa Teks Deskripsi Kelas VII SMP." SASTRANESIA: Jurnal Program Studi Pendidikan Bahasa Dan Sastra Indonesia 8 (3): 35-49. https://ejournal.stkipjb.ac.id/index.php/sastra/article/view/1520.

Halliday, M. A. K. 1971. "Language Structure and Language Fungtion." Dalam New Horizons in Linguistics, disunting oleh John Lyons, 140-65. Harmondsworth: Penguin. http://archive.org/details/newhorizonsinlinoolyon.

Kentjono, Djoko. 1982. Dasar-dasar linguistik umum. Fakultas Sastra, Universitas Indonesia.

Kridalaksana, Harimurti. 2009. "Pembentukan Kata dalam Bahasa Indonesia." Dalam, 242. Jakarta: PT Gramedia Pustaka Utama.

Lindberg-Seyersted, Brita. 1997. "'Bad' language can be good: Slang and other expressions of extreme informality in Sylvia Plath's poetry." English Studies 78 (1): 19-31. doi:10.1080/00138389708599059.

Nababan, P. W. J. 1993. Sosiolinguistik: Suatu Pengantar. Jakarta: Gramedia.

Neufeldt, Victoria. 1999. "Informality in Language." Dictionaries: Journal of the Dictionary Society of North America 20 (1). Dictionary Society of North America: 1-22. doi:10.1353/dic.1999.0000.

Ramlan. 2012. "Morfologi." Dalam . Yogyakarta: CV Karyono.

Sudaryanto. 2015. "Metode dan Aneka Teknik Analisis Bahasa." Dalam . Yogyakarta: Sanata Darma University Press.

Wardhaugh, Ronald. 2006. An Introduction to Sociolinguistics. Oxford: Blackwell.

We Are Social. 2020. "10 Media Sosial yang Paling Sering Digunakan di Indonesia." Databoks. https://databoks.katadata.co.id/datapublish/2020/02/26/10-media-sosial-yang-paling-seringdigunakan-di-indonesia.

Zen, Evynurul Laily. 2011. "Afiks Tidak Baku Dalam Bahasa Indonesia Ragam Informal." LiNGUA: Jurnal Ilmu Bahasa Dan Sastra 6 (1). doi:10.1886o/ling.v6i1.1300. 